\title{
Study on Operation Mode of Agricultural Supply Chain in WeChat Business Environment
}

\author{
Yue Cong, Yaqin Zheng \\ Business Administration School, Anhui University of Finance and Economic, Bengbu, China \\ Email: 1163254213@qq.com
}

How to cite this paper: Cong, Y. and Zheng, Y.Q. (2017) Study on Operation Mode of Agricultural Supply Chain in WeChat Business Environment. Journal of Service Science and Management, 10 , 330-337.

https://doi.org/10.4236/jssm.2017.103026

Received: June 10, 2017

Accepted: June 23, 2017

Published: June 26, 2017

Copyright $\odot 2017$ by authors and Scientific Research Publishing Inc. This work is licensed under the Creative Commons Attribution International License (CC BY 4.0).

http://creativecommons.org/licenses/by/4.0/

\begin{abstract}
With the popularity of the Internet and smart phones, it is becoming more and more common to use WeChat to maintain human relationship, share information in life, and sell various kinds of agricultural products at the moment. This paper analyzes the characteristics and current situations of operation mode in agricultural supply chain, and points out the disadvantages of modern agricultural product supply chain model, then puts forward a new operation mode of agricultural supply chain which is based on the Internet, and WeChat is regarded as the medium trading platform for the purpose of shortening the length of the supply chain and ensuring the operation efficient of agricultural supply chain.
\end{abstract}

\section{Keywords}

Wechat Business, Agricultural Product Supply Chain, Operation Mode, C2B Supply Chain Mode

\section{Introduction}

It is well known that China is the agricultural production power and the export power house, however, several factors of weak agricultural infrastructure, long and complex agricultural products circulation and recovery facilities channel, information asymmetry between supply chain upstream and downstream and the lack of cold chain logistics result in the huge loss of agricultural products. It is estimated that, supported by Internet technology and cold chain logistics technology, the loss rate of agricultural products in production and circulation in developed countries is below $5 \%$, while this index of China is as high as $25 \%$ 30\%. In March 2015, Chinese Prime Minister Keqiang Li put forward the "In- 
ternet+" action plan for the first time that adding new Internet technologies to traditional agriculture will bring a new ecology to the agricultural field. Therefore, the electronic commerce of agricultural products emerges as the time requires. In this era of people who possess a great deal of fragmentation time, mobile terminals device are widely used. As the most active social platform in mobile terminals device, the sale of agricultural products on WeChat platform has unique advantage. Apart from the advantages of ordinary e-commerce websites, WeChat also has such characteristics of low cost in promotion and rapid accumulation of chowhound and traffic.

\section{Characteristics of Agricultural Supply Chain}

The production and circulation of agricultural products which great influenced and restricted by natural conditions are very different from the traditional services and industries. Traits of fresh, perishable and seasonal determines the cold chain logistics necessary for the process of storage construction and the circulation. The supply chain of Chinese modern agricultural products has the following characteristics:

\subsection{Long Process of Agricultural Supply Chain, and Too Many Participants Involved in Each Chain}

From the producers of agricultural products, processing and distribution centers, traditional markets or large supermarkets to consumers, there are numerous of people involved in every link of the supply chain. Moreover, the traditional small-scale peasant economy in China has made the producers of agricultural products living in a more scattered way. In addition, more intermediate links result in the chain of agricultural products supply chain get longer, the joint relations among the nodes become complicated and lack of unified cooperation.

\subsection{The Production Scale of Agricultural Products Is Relatively Small and the Interests of Producers Cannot Be Guaranteed}

Since the agricultural system of contracted responsibility was put into effect in China, the enthusiasm of agricultural production has been greatly improved, while the scale of production of agricultural producers has been generally small, some core enterprises of agricultural products are more dispersed. As producers of agricultural products, that is, farmers, their own quality is not high, who cannot be well contacted and use of information networks to obtain timely supply and demand information of agricultural products supply chain, and are excluded from the supply chain of agricultural products, thus their interests cannot be guaranteed. The real profit goes to the middlemen who buy up the farm products at almost give away prices and sell at outrageous prices to the consumers [1]. In addition, the educational and cultural level of farmers is low, even if their interests are violated, they are not likely to use technology to change the status, that can only passively obey the operator's arrangement. The phenomenon of 
only producing but not selling leads to great losses to the farmers.

\subsection{Poor in Cold Chain Logistics Infrastructure Leads to Great Loss in Logistics Process}

Logistics is the key factor in the circulation of agricultural products supply chain, accelerating the development of agricultural cold chain logistics is of great significance to improve the competitiveness of agricultural products and increase rural income [2]. Agricultural products have the characteristics of being fresh and perishable, and if sellers want to obtain consumer satisfaction and maintain their loyalty, they must ensure that agricultural products are not damaged and being fresh delivered to consumers. Therefore, logistics is particularly important in the entire circulation process. However, China now adopts the normal temperature logistics and natural logistics, and the weak foundation of cold chain logistics brings great losses to the agricultural products.

\subsection{Asymmetric Information among Nodes Enterprise in the Supply Chain}

The difference of informatization between enterprises is the principal problem among the nodes of the agricultural product supply chain, China lacks a unified and core platform for all businesses to communicate and exchange the supply and demand information, which has created an inter enterprise information gap that should be mutual understanding, multilateral and win-win, and the development of agricultural products has been hindered to a great extent. Whether the supply chain can succeed in the process of controlling logistics, capital flow and information flow and maximizing the interests of the participants in the whole process mainly depend on the stability of business relationship in the supply chain. The prominent contradiction between small-scale production and large market demand in China leads to great asymmetry of information among nodes and merchants, each node's businesses are fragmented, and the business relationship between nodes is loose, which contribute to the difficulties in forming a dominant position in the supply chain and fully grasping the relationship between supply and demand in the market.

\section{Present Situation of Agricultural Supply Chain}

Since China's accession to the WTO, the obstacles in the production field have been basically solved in the process of agricultural development, and now the biggest problem faced in the agricultural products are a great deal of wear and tear in circulation. In the process of the circulation of agricultural products in China, the informatization level of each enterprise is unbalanced. The backward logistics infrastructure and the unitary payment means intensify the contradiction between the small production-scale and the large external market, which lead to the whole supply chain information flow, capital flow, business flow and logistics cannot be good docking in space and time, that hindered the development of agricultural product supply chain. 


\subsection{Asymmetric Information among Participants in Agricultural Supply Chain}

Short time for information technology to enter the field of agricultural production in China leads to lower overall level of informatization. There is no core information platform in China which is carefully planned and designed. Information between enterprises cannot be circulated and the informatization is quite different in enterprises. Information use in agriculture has increasingly become important for effective decision-making by the farming community [3]. However, there is no complete information sharing and communication between the trading entities in the supply chain, regulators such as the government have failed to act as an information exchange platform that can adopt and quickly make decisions based on information for producers, consumers and middlemen. The knowledge level of farmers in China is limited, their ability to obtain information on market supply and demand is poor, and the acquisition cost is higher, in the supply chain information acquisition process is at a disadvantage. The people who are in information acquisition advantage may keep the important information under cover for their own benefit, which leads to serious lag and distortion of information; The supply chain of agricultural products in China is longer, and there are many participants in all links. The regulators in the upper and lower levels have different information, low level of e-commerce application have hindered the integration between each link participants for effective logistics, fund flow, information flow and business flow.

\subsection{Lack of Capable Core Enterprises}

The supply chain of agricultural products should be established with some core enterprises, such way is very helpful to reach a consensus between enterprises, reduce circulation costs and improve the overall efficiency of the supply chain. At present, the core enterprises of the supply chain of agricultural products in China are mainly agricultural cooperatives, agricultural products wholesale markets and supermarkets. But most businesses have a very limited scope of business, and a weak supply chain integration and informatization consciousness. Most enterprises do not have their suitable integration organizations of production, supply, sales, thus it is difficult to become a capable core enterprises.

\subsection{Poor Logistics Infrastructure}

Logistics activities greatly affect the profit of producers, the price of food products, and the satisfaction of consumers [4]. The infrastructure construction of agricultural products logistics mainly includes facilities building of storage, packaging, processing, transportation and distribution. In addition, China's deep-seated conception of emphasis on production and despise circulation didn't changed and at the same time, these factors of lacking of marketing concepts totality, paying inadequate attention to product packaging, processing and brand value result in value-added agricultural products have not been improved. 
In other words, the logistics of agricultural products presents a state of disorder. Most of the agricultural products have high demands in the process of transportation and distribution, but the cold chain logistics of China's agricultural products is in a weak state. The development of retain freshness technology is extremely uneven throughout the country, which has not been widely used in the whole country that lead to great losses in the circulation of agricultural products. Fresh is the foundation of good sales of agricultural products, and the development of balanced and good cold chain logistics infrastructure plays an important role in the supply chain of agricultural products.

\subsection{Single Medium of Payment}

China's farmers have a lower level of education and a poor level of information literacy, who cannot make good use of modern technology to trade and pay for products. Traditionally, they are more inclined to take the face to face cash transactions, which have greatly limited the time, place and space of the transaction, resulting in lower flexibility of transactions to a great extent.

\section{Agricultural Supply Chain Model in WeChat Business Environment}

\subsection{Agricultural Supply Chain Model in E-Commerce Environment}

Information is the nervous system in the circulation of agricultural products. The participants in the supply chain make correct decisions, optimize the allocation of product resources, and achieve seamless docking of the various transactions through the sharing of information. At present, the information network of agricultural products is imperfect, and the information is scattered and complicated. The ability of each node member to acquire and process information varies greatly. The information network and communication facilities are relatively backward. Therefore, China must build a standardized and efficient information network system, and widely adopt modern information network technology to speed up the integration of agricultural products and the internet, that establish a supply chain operation model of agricultural products based on Internet environment. Producers and consumers are linked together through network information technology, which can reduce the intermediate link of the supply chain, what's more, effective tracking and control of all links in the supply chain can be achieved, that maximize the benefits of each node member in the supply chain. With the arrival of Web 2.0, social networks shaped social patterns and changed the ways that people communicate, which is playing an increasingly important role in the sales of products and services. As China's highest liveness social software, WeChat's information transfer mechanism has solved the problem that the slack information flow between the supply chain entities, and strengthened the unification of production and sales in the process of agricultural products circulation. 


\subsection{The Model Content of Agricultural Supply Chain in WeChat Business Environment}

WeChat business of agricultural products supply chain is adopted C2B mode, which makes a full integration of the social networking platform for information exchange, through a predetermined system consumption, with sales to determine the yield, changed the traditional agricultural production, storage, packaging, processing, logistics and distribution mode that reverse the traditional agricultural products supply chain. C2B ( $\mathrm{C}$ refers to customers, B refers to enterprises) supply chain model refers to WeChat business share the information and services of agricultural products in the form of story in the moment, consumers issued orders and down payment to the WeChat business. After gathering a certain quantity of orders, the WeChat business issued a large order to the agricultural production base. Finally, through the outsourcing of the third party logistics, agricultural products are sent to consumers, then customers give the feedback to the quality of products and service.

Agricultural supply chain of C2B is "Consumer-Network platform-Producer". This is contrary to the traditional supply chain model of agriculture, which consumers occupy the core position. The supply chain of agricultural products $\mathrm{C} 2 \mathrm{~B}$ the initial rise in the United States, the main purpose is to put the large number and scattered consumers together, forming a large range of discount group, thereby reducing the cost to consumers and changing the weak prospect state of one to one bids by consumers. With today's market globalization and increased competitive pressures, companies are forced to move from making decoupled decisions to coordinated and integrated decisions [5]. The same concept can be applied to WeChat business in $\mathrm{C} 2 \mathrm{~B}$ agricultural supply chain. Each node enterprise carries on the information dissemination through the moment or subscribe account to integrate consumers into a large demand group, which can enjoy the preferential price given by the producers of agricultural products. This kind of supply chain model of agricultural products transforms the traditional agricultural products producers' active marketing into the consumers' active purchase mode, that is to say, changing the "promoting sales" to "stimulating production". Making an advanced planning for agricultural production so that it can be more effective coordination of the upstream and downstream supply chain information.

\section{Advantages of Agricultural Supply Chain in WeChat Business Environment}

With the help of Internet, especially the communication advantages provided by WeChat platform, the supply chain of agricultural products in the WeChat business environment has a tremendous advantage over the traditional supply chain of agricultural products. First of all, the way of direct collection from the country of origin can control the quality of agricultural products from the fountainhead which increase the consumer's confidence in the quality of products. At the same time, agricultural products from producers directly to consumers can 
reduce the flow of intermediate links, shorten the length of the supply chain, reduce the loss of agricultural products, and improve the overall efficiency of the supply chain of agricultural products; Secondly, the C2B supply chain is the "reserve + group-buying", which belongs to predetermined consumption. Through pre-sale, you can advance acquire the number of user orders, and then use the order quantity to determine production, which will reduce farmers' unsalable of agricultural products caused by information obstruction.

\subsection{Shorten the Length of Supply Chain}

There are too many links in the production, processing and transportation of China's agricultural links that result in the supply chain longer, and vary dramatically in informatization degree of each participant in the supply chain, which not only weakens the interests of the participants in each node, but also restricts the development of agricultural products to a great extent. However, C2B's agricultural supply chain model is sent production directly from the origin place to the consumer, that shortening the middle circulation, reducing the loss of products and saving the extra cost caused by the loss.

\subsection{Product Storify and Forming Brand Effect}

The marketing of agricultural products in this supply chain takes place in the form of direct marketing, WeChat business of farm products permeate to the upstream base, control the quality of the product directly from the source, and bring good quality experience to consumers. With the increasing consumption level of our country, the consumers are not only pursuing the quality of products, but also paying more attention to the stories behind the products, the individuation and the uniqueness of the products. WeChat agricultural products excavated the story behind the product, through the colorize, figurative metaphor and visual image to prominent the product brand.

\subsection{Collaborate the Information Flow in Agricultural Supply Chain}

Increasing globalization has brought the technology and information to enhance vertical integration in agricultural supply chain [6]. Consumers come to know the product information from the form of video, pictures or text in the moment or subscribe account. Consumers issued the advance order to WeChat business after gathered a certain quantity, the dealer issued an order to the agricultural products base. This way of determining output by volume of sales has reduced the ratio of farmers' blind production, providing certain guarantee for the production and sale of farmers, and greatly reducing the losses caused by unmarketable agricultural products. A collaboratively integrated information sharing process could strengthen partners' information sharing internally and externally [7]. As the core of information publishing and delivery, WeChat plays a key role in information releasing and integration and whole supply chain controlling which helps to achieve traceability of product information, solve the unsalable 
matter caused by asymmetric information among enterprises of all nodes and remain the price of agricultural products stable.

\section{Conclusion}

With the development of Internet technology, the application of e-commerce permeates all walks of life, as a social networking platform, WeChat business can not only get through the upstream and downstream supply chain information, but also can eliminate the large number of unsalable products because of the poor circulation of information and the matter of public complained about the high price of vegetables. This paper mainly discusses the present situation of modern agricultural products supply chain model, analyses it's weaknesses, and makes a new construction of agricultural supply chain mode in the WeChat business environment, eliminating the information asymmetry between buyers and sellers of agricultural products and shortening the length of supply chain to ensure each node population's interests of the supply chain.

\section{Fund Project}

Anhui philosophy and social science planned project: Study on the Countermeasures for developing e-commerce of characteristic agricultural products in Anhui under the "Internet+" new norm (AHSKY2015D86);

Anhui philosophy and social science planned project: Study on the Countermeasures of agricultural products e-commerce in Anhui Province Based on the direct selling of origin place (AHSKY2014D10).

\section{References}

[1] Oguoma, O.N., Nkwocha, V.I. and Ibeawuchi, I.I. (2010) Implications of Middlemen in the Supply Chain of Agricultural Products. Journal of Agriculture \& Social Research, 10, 77-83.

[2] Shen, X., Liu, L. and Huang, Z. (2013) Investigation and Analysis of Agricultural Cold Chain Logistics and Its Development Strategy in Heilongjiang Province. Asian Agricultural Research, 5, 80-82.

[3] Ali, J. and Kumar, S. (2011) Information and Communication Technologies (ICTs) and Farmers' Decision-Making across the Agricultural Supply Chain. International Journal of Information Management, 31, 149-159.

[4] Bosona, T.G. and Gebresenbet, G. (2011) Cluster Building and Logistics Network Integration of Local Food Supply Chain. Biosystems Engineering, 108, 293-302.

[5] Jang, W. and Klein, C.M. (2011) Supply Chain Models for Small Agricultural Enterprises. Annals of Operations Research, 190, 359-374. https://doi.org/10.1007/s10479-009-0521-8

[6] Reardon, T. and Barrett, C.B. (2000) Agro-Industrialization, Globalization and International Development: An Overview of Issues, Patters, and Determinants. Agricultural Economics, 23, 195-205.

[7] Eksoz, C., Mansouri, S.A. and Bourlakis, M. (2014) Collaborative Forecasting in the Food Supply Chain: A Conceptual Framework. International Journal of Production Economics, 158, 120-135. 
Submit or recommend next manuscript to SCIRP and we will provide best service for you:

Accepting pre-submission inquiries through Email, Facebook, LinkedIn, Twitter, etc. A wide selection of journals (inclusive of 9 subjects, more than 200 journals)

Providing 24-hour high-quality service

User-friendly online submission system

Fair and swift peer-review system

Efficient typesetting and proofreading procedure

Display of the result of downloads and visits, as well as the number of cited articles Maximum dissemination of your research work

Submit your manuscript at: http://papersubmission.scirp.org/

Or contact jssm@scirp.org 